\title{
A házasság és a család mint keresztény és európai értékek
}

\section{VARGA ZS. ANDRÁS}

A tanulmány áttekinti a házasságra és a családra vonatkozó legfontosabb nemzetközi emberi jogi dokumentumokat. Ezek rendelkezéseit tárgyuk szerint csoportosítva kísérel meg következtetést levonni a két társadalmi jelenség nemzetközi jogi védelmének jellegére. Ezt követöen áttekinti, hogy a házasság és a család mennyire tekinthetö az európai kultúra lényeges összetevöjének. Az ószövetségi zsidó és a római birodalmi jog házasságfelfogásából kiindulva, az ezeket az értékeket továbbvivő Katolikus Egyház szabályainak áttekintése után bemutatja a kortárs egyetemes és hazai egyházi felfogást. Mindennek eredményeként vonja le azt a következtetést, hogy az európai kultúra a bemutatott házasság-és családfelfogásra épül. Ennek elvetése vagy lehetetlen, vagy egy másik kultúra létrehozását jelentené.

Kulcsszavak: házasság, család, ószövetség, római jog, kereszténység, Egyház, kánonjog, nemzetközi jog, emberi jogok, kultúra

\section{Marriage and Family as Christian and European Values}

The study overviews the basic international human rights instruments on marriage and the family. By grouping their provisions according to their substantive content, it seeks to draw a conclusion as to the nature of the protection of the two social phenomena under international law. It then reviews the extent to which marriage and family can be seen as essential components of European culture. Starting from the conception of marriage in Old Testament, the Jewish and Roman imperial law, it presents the contemporary universal and domestic ecclesiastical conception after reviewing the rules of the Catholic Church, which conveys these values. As a result, the study concludes that the European culture is based on the conception of marriage and family presented. The rejection of these values would be either impossible or would create another culture.

Keywords: marriage, family, Old Testament, roman law, Christianity, church, canon law, international law, human rights, culture

1 Tanszékvezető egyetemi tanár, PPKE JÁK; e-mail: varga.zs.andras@jak.ppke.hu 
Az Alaptörvény legtöbbet kritizált rendelkezési közé tartozik a Nemzeti hitvallásnak a családra utaló akklamációja - „Valljuk, hogy együttélésünk legfontosabb keretei a család és a nemzet, összetartozásunk alapvető értékei a hűség, a hit és a szeretet” -, és az L) cikk, amelynek (1) bekezdése szerint „Magyarország védi a házasság intézményét mint férfi és nő között, önkéntes elhatározás alapján létrejött életközösséget, valamint a családot mint a nemzet fennmaradásának alapját. A családi kapcsolat alapja a házasság, illetve a szülő-gyermek viszony".2 A kifogások jellemzően a házasság és a család fogalmának összekapcsolását, a társadalmi élet és a jogi értékrend középpontjába állítását, az individuális önrendelkezéssel szembeni korlátozó hatását érintik. ${ }^{3}$ Kétségtelen, hogy a nemzetközi emberi jogi dokumentumok jóval kevésbé kategorikusan fogalmaznak. Elsősorban a házasságkötés szabad elhatározására, illetve a már létező család tiszteletben tartására helyezik a hangsúlyt. Ebben a tanulmányban először a hatályos nemzetközi jogi környezetet tekintem át, majd megkísérlem bemutatni, hogy az egy férfi és egy nő közötti házasság keresztény értelmezése miért elválaszthatatlan az európai társadalmi és jogfelfogástól. Végül azt a következtetést próbálom megalapozni, hogy az Alaptörvény szövege egyszerre tükrözi a keresztény és a hagyományos európai felfogást, ugyanakkor nincs ellentétben Magyarország nemzetközi jogi kötelezettségeivel sem.

\section{Házasság és család a nemzetközi alapjogi szövegekben}

A legfontosabb, a nemzetközi jogfejlődés sarokpontjait jelentő dokumentumok mindegyikében találkozunk a házasságra és a családra - föként e jogintézmények védelmére - vonatkozó rendelkezésekkel. A sort az Emberi jogok egyetemes nyilatkozata (EJENY) nyitja, amely ugyan nem kötelező erejü, de rendelkezései visszaköszönnek a már kötőerejú két egyezségokmányban, a az Egyesült Nemzetek Közgyülése XXI. ülésszakán, 1966. december 16-án elfogadott Polgári és Politikai Jogok Nemzetközi Egyezségokmányában (PPJNE) és az Egyesült Nemzetek Közgyűlése XXI. ülésszakán, 1966. december 16-án elfogadott Gazdasági, Szociális és Kulturális Jogok Nemzetközi Egyezségokmányában (GSZKJNE), amelyeket Magyarországon az 1976. évi 8., illetve 9. törvényerejü rendelet hirdetett ki. Közelebbi környezetünkben - még az egyezségokmányok elfogadása előtt - az emberi jogok és alapvető szabadságok védelméről szóló, Rómában, 1950. november 4-én kelt egyezmény (EJEE), amelyet már a rendszerváltozás után az 1993. évi XXXI. törvény hirdetett ki, szintén rendelkezik a két jogintézményről. A legfontosabb okmányok sorát az Európai Unió (EU) Alapjogi Chartája zárja, amelyet 2000. december 7-én írták alá a nizzai csúcs-

2 Az Alaptörvény erre vonatkozó eredeti szövegének kialakulásáról 1. Varga Zs. András: A házasságra és a családra vonatkozó rendelkezések változása az alkotmányozás során. Iustum Aequum Salutare, 8. (2012), 2. 119-127. A szövegek az Alaptörvény negyedik és hetedik módosításai során kiegészültek.

3 Csak példaként: Pap András László: Ki és mi a magyar? Az Alaptörvény preferenciái kritikai perspektívából. In Gárdos-Orosz Fruzsina - Szente Zoltán (szerk.): Alkotmányozás és alkotmányjogi változások Európában és Magyarországon. Budapest, NKE KTK, 2014. 245-64. 
találkozón, és amely az Európai Unióról szóló Szerződés 6. cikk (1) bekezdése alapján a lisszaboni szerződés hatálybalépése óta (2009. december 1.) kötelező erejű elsődleges uniós jogforrás. Mivel a fenti jogforrások szövege nagyon hasonló, célszerűbb ezeket nem időrendben (vagy jogforrásonként), hanem a legfontosabb rendelkezéseik tartalma alapján bemutatni.

\subsection{A házasság és a család társadalmi szerepe}

Érdekes módon a család társadalmi szerepéről és ennek jelentőségéről csak az EJENY és a két egyezségokmány rendelkezik. Mindez mutatja, hogy a nemzetközi egyezmények elfogadása során a részes felek már több mint fél évszázada is óvatosak voltak. Konkrét részletszabályok megfogalmazására készen álltak, de nem kívánták elkötelezni magukat a jogintézmény lényegének meghatározásával.

Az EJENY, amely (két évvel azután jött létre, hogy az Egyesült Nemzetek Szervezete már alapokmányában kiemelte - és ezzel a nemzetközi jog kötelező szabályává emelte - az emberi jogok tiszteletben tartását $)^{4}$ nem jogi kötőerővel bíró megállapodás ugyan, de figyelemmel arra, hogy nyolc tartózkodás mellett ${ }^{5}$ - minden tagállam elfogadta, mégpedig ellenszavazat nélkül, óriási jelentőségű. Olyan dokumentum ugyanis, amelynek értékrendjét minden kultúra és minden nemzet magáénak tudja vallani. Az EJENY a 16. cikkében úgy fogalmaz, hogy a férfinak és a nőnek joga van fajon, nemzetiségen vagy valláson alapuló korlátozás nélkül házasságot kötni és családot alapítani, a házasság tekintetében egyenlő jogaik vannak, a család pedig a társadalom természetes és alapvető alkotóeleme, amelynek (a családnak tehát, és nem a tagjainak!) joga van a társadalom és az állam védelmére. ${ }^{6}$ Az EJENY szövegének utolsó elemét, a definiáló rendelkezést lényegében változatlanul ismétli meg a PPJNE 23. cikke, és kiegészítve erősíti meg a GSZKJNE 10. cikke:

„Az Egyezségokmányban részes államok elismerik, hogy

1. a lehető legszélesebb körű védelmet és segítséget kell nyújtani a családnak, amely a társadalom természetes és alapvető egysége, különösen a családalapítás tekintetében és addig, amíg a család felelős az eltartott gyermekek gondozásáért és neveléséért."

Az EJENY és az egyezségokmányok nem maradtak hatás nélkül Magyarországon sem. Hazai adaptációjukat az Alkotmánybíróság végezte el egyik első, a 4/1990. (III. 4.) $\mathrm{AB}$ határozatában: „A társadalmat alkotó polgárok legalapvetőbb és legtermészete-

$4 \quad$ Kardos Gábor: Az emberi jogok nemzetközi védelmének általános kérdései. Elérhető: www.ajkhok. elte.hu/jegyzettar (A letöltés dátuma: 2020. 10. 08.)

5 Az Emberi jogok egyetemes nyilatkozata: az első globális közlemény a velünk született méltóságról és egyenlőségről. Elérhető: www.unis.unvienna.org (A letöltés dátuma: 2020. 10. 08.)

6 Frivaldszky János: Természetjog és emberi jogok. Budapest, PPKE JÁK, 2010. 7. 
sebb közössége a házasság és a család." A következményeket pedig a már hivatkozott 14/1995. (III. 13.) AB fogalmazta meg: ${ }^{7}$

„a házasság intézménye kultúránkban és jogunkban is hagyományosan férfi és nő életközössége. Ez az életközösség tipikusan közös gyermekek születését és a családban való felnevelését célozza, amellett, hogy a házastársak kölcsönös gondoskodásban és támogatásban élésének is kerete. A gyermekek nemzésére és szülésére való képesség nem fogalmi eleme és nem feltétele a házasságnak, de a házasság eredeti és tipikus rendeltetéséből folyóan a házastársak különneműsége igen. A házasság intézményét az állam arra tekintettel is részesíti alkotmányos védelemben, hogy elősegítse a házastársak számára a közös gyermekkel is rendelkező család alapítását. Ez a magyarázata annak, hogy az Alkotmány 15. \$-a együtt említi a védelem két tárgyát."

Ebben a határozatában az Alkotmánybíróság azt is világossá tette, hogy a házasság férfi és nő kapcsolatakénti meghatározása miért nem valósít meg alkotmányellenes diszkriminációt: „Két személy tartós életközössége megvalósíthat olyan értékeket, hogy az érintettek személyi méltóságának egyenlő figyelembevétele alapján az együtt élő személyek nemétől függetlenül igényt tarthat jogi elismerésre. Az azonos elbánás mindig a jogi szabályozás tárgyát képező életviszonytól függően mérlegelendő." Ugyanakkor azt is rögzíti - és talán ez a legbelsőbb magva a határozat indokolásának -, hogy „férfi és nő egyenjogúságának addig van értelme, amíg a férfi és nő közötti természetes különbséget elismerjük, s erre figyelemmel valósul meg az egyenjogúság”.

Ezt az adaptációs folyamatot, a házasság és az azon alapuló család megkülönböztetett védelmének biztosítását zárta le végül az Alaptörvény már hivatkozott L) cikke. A házasságra és a családra vonatkozó részletszabályok tekintetében kevésbé látványos a szövegek fejlődése.

\subsection{A házasságkötéshez való jog és a házastársak egyenlősége}

Az első részjogosultság, amelyet a dokumentumok szabályoznak, az Európában ekkorra lényegében általánossá vált, de más kultúrákban még korántsem magától értetődő szabad házasságkötési jog és a házasfelek egyenjogúsága. Az EJENY már hivatkozott 16. cikke rögzíti tehát, hogy a férfinak és a nőnek a házasságra érett kor elérésétől kezdve joga van fajon, nemzetiségen vagy valláson alapuló korlátozás nélkül házasságot kötni és családot alapítani, illetve hogy a házasság tekintetében a férfinak és a nőnek mind a házasság tartama alatt, mind a házasság felbontása tekintetében egyenlő jogai vannak. Világossá teszi azt is, hogy kifejezetten jogról, és nem (főként családi nyomásra létrejövő) kötelességről van szó, amikor kijelenti, hogy házasságot

7 Ld. erről részletesen: Schanda Balázs: Házasság és család az alkotmányjogban. In Csink Lóránt - Schanda Balázs - Varga Zs. András: A magyar közjog alapintézményei. Budapest, Pázmány Press, 2020. 681-701. 
csak a jövendő házastársak szabad és teljes beleegyezésével lehet kötni. Ezt ismétli meg és egészíti ki a részes államok aktív szabályozási kötelezettségének kimondásával a PPJNE 23. cikke és a GSZKJNE 10. cikke.

Az EJEE 12. cikke lényegében megismétli az EJENY és az egyezségokmányok szövegét minden pontosítás nélkül. A pontosítást a Hetedik kiegészítő jegyzőkönyv 5. cikke hozza, amely szerint „,[a] házastársaknak polgári jogi vonatkozásokban egyenlő jogaik vannak, és felelősségük is egyenlő egymás közötti, valamint a gyermekeikkel való kapcsolataikban a házasság tekintetében, annak tartama alatt és felbontása esetében." Hozzáteszi továbbá, hogy a rendelkezés nem gátolja az államokat abban, hogy a gyermekek érdekében szükséges intézkedéseket tegyenek.

Az Alapjogi Charta még ennél is szủkszavúbb, mindössze annyit ír elő, hogy a házasságkötéshez és a családalapításhoz való jogot az e jogok gyakorlását szabályozó nemzeti törvények szerint biztosítani kell. Vélhetően nem tévedünk, ha feltételezzük, hogy a szűkszavúság magyarázata az, hogy a 21. századra Európa egészében megváltozott - mondjuk ki, csökkent - a házasságnak a társadalom életében betöltött és az EJENY által még elismert alapvető szerepe. Ezzel együtt jelentőséget kell tulajdonítanunk annak, hogy a házasság jogintézményének tagállami szabályozását kötelezőnek tartja.

\subsection{A család mint a magánszféra részének védelme}

Az előzőnél is kevesebb eltérést találunk a család ügyeibe történő illetéktelen beavatkozás tilalmának tekintetében, amit a hivatkozott szövegek a magánszféra, a becsület és a jóhírnév védelme körében oldanak meg. Az EJENY 12. cikkének megfogalmazása szerint senkinek a magánéletébe, családi ügyeibe, lakóhelye megválasztásába vagy levelezésébe nem szabad önkényesen beavatkozni, sem pedig becsületében vagy jóhírnevében megsérteni. A PPJNE 17. cikke, az EJEE 8. cikke és az Alapjogi Charta 7. cikke lényegében hasonlóan rendelkezik. Az alapvető szöveghez mindössze az EJEE ad hozzá releváns tartalmat, amikor a korlátozás okait és mértékét is meghatározza: „E jog gyakorlásába hatóság csak a törvényben meghatározott, olyan esetekben avatkozhat be, amikor az egy demokratikus társadalomban a nemzetbiztonság, a közbiztonság vagy az ország gazdasági jóléte érdekében, zavargás vagy bűncselekmény megelőzése, a közegészség vagy az erkölcsök védelme, avagy mások jogainak és szabadságainak védelme érdekében szükséges."

\subsection{A család szociális biztonságának védelme}

Valamivel részletesebb, de témánk szempontjából a legkevésbé érintett kérdés a család szociális biztonságának védelme. Egyrészt azért, mert itt már nem tisztán közjogi kérdésről beszélhetünk, másrészt azért, mert Európában egyre kevésbé tartósak a családi kapcsolatok, és még ennél is kevésbé jelennek meg a nemzetgazdaságban (a korábbi korszakokhoz képest mindenképpen), harmadrészt azért, mert a családtámogatás 
már csak kevés helyen meghatározó (Magyarország ebben a tekintetben a reményt keltő kivételek közé tartozik), leggyakrabban kimerül a gyermekvédelem-gyermektámogatás eszközeiben. Nyilván fontos lenne ezt alaposabban körüljárni, de ez önmagában egy másik tanulmányt érdemelne.

Mindenesetre az EJENY 23. cikke szerint „[m]indenkinek, aki dolgozik, olyan méltányos és kielégítő fizetéshez van joga, amely számára és családja számára az emberi méltóságnak megfelelő létet biztosít, és amelyet megfelelő esetben a szociális védelem összes egyéb eszközei egészítenek ki”. A 25. cikk részletezi is ezt, amikor felsorolja, hogy a megfelelő jövedelemhez való jog mire terjed ki: az egyén saját maga és családja egészségének és jólétének biztosítására alkalmas életszínvonalra, élelemre, ruházatra, lakásra, orvosi gondozásra, valamint a szükséges szociális szolgáltatásokra, munkanélküliség, betegség, rokkantság, özvegység, öregség, valamint mindazon más esetekre szóló biztosításra, amikor létfenntartási eszközeit akaratától független körülmények miatt elveszíti. Külön nevesíti az anyasági és a gyermektámogatásokhoz való jogot (a házasságból és a házasságon kívül született gyermekek tekintetében is). Ezt az egyezségokmányok, különösen a GSZKJNE tovább cizellálják.

Az EJEE erről a jogról egyáltalán nem ejt szót, az Alapjogi Charta pedig, tükrözve az egyezségokmányok elfogadását követő évtizedek alapvető szemlélet- és értékrendbeli változását, a 33. cikkében már csak a család jogi, a gazdasági és a szociális védelmének absztrakt elvét jelenti ki, két konkrét szabály, a gyermekvállalással összefüggő okból történő elbocsátás tilalma, valamint a fizetett szülési és szülői szabadság előírása mellett (anélkül, hogy ez utóbbinak legalább a minimális mértékét megjelölné).

A II. világháborút követő nemzetközi és európai szabályok vázlatos áttekintése után azt látjuk, hogy a házasság és a családok védelme változó (inkább csökkenő) mértékben ugyan, de jelen van a nemzetközi dokumentumokban. Kijelenthetjük tehát, hogy a házasságot és a családot a nemzetközi jog ma is elismeri és védi.

\section{A keresztény házasság- és családfelfogás alapvonásai}

Nézzük meg most a két jogintézmény tágabb és időben távolibb európai kulturális hátterét! Kezdjük ezt annak feltárásával, hogy milyen szerepet töltött be a család a megszülető, majd kialakuló kereszténység mindennapi életében. A keresztényüldözések korában, az első évszázadokban az egyházi élet (mindenekelőtt a szentmise) résztvevői csak a megkereszteltek voltak, mivel a hittitok (arcanum vagy mysterium fidei) megőrzése érdekében más nem ismerhette meg a keresztény hit és főként hitgyakorlat részleteit és lefolyását. ${ }^{8} \mathrm{E}$ szempont mögött akkor is háttérbe került a család közös részvétele a kenyértörésben, ha a család (főként a házasság) keresztény értelmezése mindvégig kiemelt jelentőséggel bírt (komoly szabályok vonatkoztak a ke-

8 Henry Chadwick: A korai egyház. Budapest, Osiris, 2003. 29-30.; Kránitz Mihály: A keresztény hit kialakulása és védelme. Budapest, Szent István Társulat, 2018. 22-24.; Erdő Péter: Az ókori egyházfegyelem emlékei. Budapest, Szent István Társulat, 2018. 151. 
resztény és a pogány közötti házasságra, illetve a családi állapotra kiható bűnökre9). Az üldözés megszűnését követően, különösen a gyermekkeresztelés bevezetése és a keresztényekből álló családok általánossá válása után jelentkezhetett (vagy legalábbis válhatott általánossá) a kisgyermekes családok megjelenése az Eucharisztia ünneplésén. A későbbi évszázadokban a liturgia egyre ünnepélyesebbé (és ezáltal merevebbé) válása során ez általános problémát nem okozhatott, mivel közismert emlék nem maradt fenn róla. Az mindenesetre tény, hogy a szentmise a hitre nevelés helye is volt. Erre utalnak Alexandriai Szent Kürillosz katekézisei és a későbbi források is. ${ }^{10}$ A II. Vatikáni Zsinat utáni korszak viszont nemcsak a hívek egyházi (és a liturgiában betöltött) szerepét illetően hozott változást, hanem a család (talán éppen a krízise által kiváltott) jelentőségének felismerése által is.

\subsection{A család jelentősége a kereszténység kialakulása idején}

A Római Birodalom Iudaeát is magában foglaló provinciájában megszülető kereszténység nyilvánvalóan azt a családmodellt tekintette magáénak, amely Jézus Krisztus első követői, az apostolok, a többi tanítvány, majd a zsidóságból és a kereszténységből megtértek számára eleve adott volt. Különösen, hogy a pogány római és az ószövetségi zsidó családfelfogás alapjaiban nem tért el egymástól, mindkettő a családfő kiemelt szerepe által összefogott, monogám házasságon alapuló rokonságra és vérségi leszármazásra épült.

\subsubsection{A római családjog}

A római magánjog a házasságnak (matrimonium) és a leszármazásnak egyaránt jelentőséget tulajdonított. ${ }^{11} \mathrm{Az}$ agnat (az apai hatalom által közvetített) családhoz a családfőn (pater familias) kívül a feleség (uxor) és „az apai férfi vérrokonok és ugyanannak a famíliának férfiági lemenői,"12 vagyis az apa gyermekei és ezek feleségei, unokái, örökbefogadott gyermekei és ezek feleségei, valamint gyermekei tartoztak. ${ }^{13}$ Az agnatio alapja tehát a házasságon alapuló vérrokonság volt. Emellett a római jog ismerte a kizárólag a leszármazást alapul vevő (tehát a házasság szerepe nélkül értelmezett) vérrokonságot, a cognatiót, amely már nem kizárólag az apai (hatalmon alapuló), hanem az apai és az anyai leszármazást is figyelembe vette. A cognat rokonok közé tehát

9 Ld. privilegium Paulinum, 1Kor 7,12-15; Traditio Apostolica XV, 6-; Didaszkália II-II; Apostoli kánonok XVII; Elvirai zsinat VIII-, XV-VIII, LXI-XXII; Arles-i zsinat, X-I. In Erdő i. m. (8. lj.) 140., 163-173., 340., 366., 368-369., 380-383., 388.

10 Kránitz i. m. (8. lj.) 30-35.

11 Brósz Róbert - Pólay Elemér: Római jog. Budapest, Tankönyvkiadó, 1989. 148-155.

12 Domitius Ulpianus: Domini nostri sacratissimi principis Iustiniani iuris enucleati ex omni vetere iure collecti digestorum seu pandectarum, D. 11.4. (A továbbiakban: Ulp. D.)

13 A teljes férji hatalommal járó (manus) és a szabadabb házassági forma, továbbá a nem római polgárok házassága közötti különbség bemutatását mellőzzük, mert a dolgozat témájához közvetlenül nem kapcsolódik. 
nem számították be a házasságot, vagyis a feleségeket (és persze a nőági cognatio esetén a férjeket), mivel ők egymással értelemszerűen nem álltak vérségi kapcsolatban (ez utóbbi kapcsolatot a sógorság - affinitas - jelölte). A két fogalommal értelmezett rokonság jelentős részben átfedte egymást. Így a gyermekek agnatio és cognatio alapján is az apa családjához tartoztak (míg az anyáéhoz csak cognatio alapján).

A házasságnak és a rokonságnak személyállapoti és vagyonjogi következményei is voltak. Így a vagyonközösség (consortium), az apa jogi helyzetének (római polgárság) átszállása, az örökösi státusz az apa (családfö) halála esetén (heredes). A házasság létrejöttéhez szükséges feltétel a házasságképesség (conubium), a kizáró feltételek (házassági akadályok) hiánya és a formához kötött kölcsönös ígéret volt (nuptias enim non concubitus, sed consensus facit $\left.{ }^{14}\right)$. Mindennek hatása világosan felismerhető a katolikus egyházjog házassági szabályai között, ${ }^{15}$ az intézményi (formai) kereteket tehát ez adta a keresztény házasság- és családfelfogáshoz.

\subsubsection{Izrael törvényei a házasságról és a családról}

A zsidó család (szociológiai értelemben legalábbis) nem tért el a római családtól. ${ }^{16}$ Patriarchális (a családfő hatalmi elsőbbségén alapuló) monogám házasságon és vérségi leszármazáson alapult. A különbség tehát nem formai, hanem tartalmi természetü volt. A tartalmi különbséget pedig a házasság szakrális jellege, „Isten akaratából fakadó intézménynek"17 tekintése jelenti (Ter 1,28; 2,24). Ez a szakrális jelleg nem zárta ki a válást (még ha kivételesnek is tekintette), vagyis alapjaiban az intézményi hasonlóság a római és a zsidó házasságmodell között megmaradt. Ugyanakkor a szentségi jelleg nem korlátozódott a házasságra, hanem kiterjedt a vérségi leszármazásra is. A leszármazás jelentette ugyanis azt a megkülönböztető jegyet, amely folytán egy személy a zsidósághoz mint Isten (JHVH) saját maga számára kiválasztott, mindenki mástól megkülönböztetett népéhez tartozását megalapozta. Ezt igazolják az Ószövetség könyveiben gyakran előforduló nemzetségtáblák, a leszármazás megjelölése a jelentősebb személyiségek esetén, ${ }^{18}$ sőt ez alapozta meg a nép életében betöltött szerepeket is (például a papsági feladatok ezért kapcsolódtak egyetlen törzshöz, Lévi törzséhez ${ }^{19}$ ). Sőt JHVH és Izrael kapcsolatára is használatos a házasság képe: „Maga Teremtőd lesz hitvesed, a Seregek Ura a neve" (Iz 54,5).

A házasságnak és a családnak ezt a szentségi sajátosságát tükrözik vissza az Ószövetség jogi szövegei is. A jogrend egésze szakrális, JHVH és népe kapcsolatát

14 Ulp. D. 35.1.15.

15 Erdő Péter: Egyházjog. Budapest, Szent István Társulat, 2003. 503., 509-510.

16 Kocsis Imre: Bevezetés az Újszövetség kortörténetébe és irodalmába, I. Budapest, Szent István Társulat, 2014. 27-28.

17 Uo. 27.

18 Rózsa Huba: Bevezetés az Ószövetség könyveibe. Budapest, Szent István Társulat, 2016. 178., 183., 186., 241-243.; Szathmári Béla: Magyar egyházjog. Budapest, Századvég, 2004. 383-384.

19 Rózsa i. m. (18. lj.) 204. 
Szabályozza (ld. kiemelten a szűkebb értelemben ${ }^{20}$ vett Szentség törvényét: „Legyetek szentek, mert én, az Úr, a ti Istenetek szent vagyok" Lev 19,2), így szakrálisak a mindennapi életet részletesen szabályozó jogi szövegek is. Kiemelést érdemel, hogy a szükebb értelemben vett Szentség törvényét nyomban a családra és a szombatra vonatkozó szabály követi, ami szintén a szakrális jelleg vitathatatlanságára utal: „Mindenki tisztelje anyját és apját. Tartsátok meg szombatomat. Én vagyok az Úr, a ti Istenetek" (Lev 19,3). A házasság és a család fontosságára utal a Tízparancsolat (Dekalógus) több előírása is (tiszteld apádat és anyádat; ne törj házasságot, ne kívánd embertársad feleségét; Kiv 20,12-17, Mtörv 5,16-21). Ez a szakrális jelleg vonatkozik a különféle formákban fennmaradt jogi szövegekre, amelyek több helyen rendelkeznek a házasságról és a családról. ${ }^{21}$

\subsubsection{A keresztény házasság-és családfelfogás alapvonásai}

A Jeruzsálemben megszülető, majd negyedszázad alatt a Római Birodalom minden jelentős részén elterjedő kereszténység tehát szociális és vallási okból egyaránt a házasság és a család tiszteletét hordozta. A keresztény felfogás jelentős újdonságával a vallási, szakrális jelentőségben találkozunk. Egyfelől - és ez a szempont a pogányságból megtértek esetén látványos - az Isten új népéhez tartozás már nem a leszármazáson, hanem a keresztségen és az ennek feltételéül támasztott Jézus Krisztus istenségében és megváltó művében való személyes hiten alapszik. ${ }^{22} \mathrm{Az}$ első századokban tehát a kereszténységhez tartozás, az istengyermekség nem a közösségbe beleszületésen, hanem a személyes döntésen alapszik. Másfelől azonban a házasság szakrális, szentségi jelentősége erősödik. Az evangéliumok tanúsága szerint Jézus Krisztus megszünteti a házasság ószövetségi kivételes felbonthatóságát („»Mózes megengedte, hogy válólevelet írva elküldjük az asszonyt « felelték. Jézus folytatta: »Szívetek keménysége miatt írta ezt a parancsot. De Isten a teremtés kezdetén férfit és nőt alkotott. Az ember ezért elhagyja apját, anyját, a feleségéhez ragaszkodik, és ketten egy test lesznek. Ettől kezdve többé már nem két test, hanem csak egy. Amit tehát Isten összekötött, azt ember ne válassza szét «" Mk 10,4-9), sőt kifejezetten tiltja a válást és az újraházasodást (Mk 10,11-12). Ugyanezt a szembeállitást emeli ki a hegyi beszéd a boldogságmondásokat követő két antitézisben. ${ }^{23}$ Ezáltal emelkedik az Isten akaratából származó, így természetjogi alapon felbonthatatlannak és egységnek értelmezett házasság a szentség rangjára. ${ }^{24}$

A Jézus Krisztusba vetett személyes hiten alapuló egyháztagság hatására a kereszténység belső jogának természete is megváltozott. Megmaradt a jogtisztelet, sőt a jog alapjainak végső soron a teremtő Istentől származásának felfogása, ugyanakkor - mint

20 Tágabb értelemben a Szentség törvényén a Lev 17-16 fejezeteinek egészét értjük, ld. uo., 156., $164-165$.

21 Uo. 156-165.; Szathmári i. m. (18. lj.) 394., 401., 423.

22 Kránitz Mihály: Alapvető hittan. Budapest, Szent István Társulat, 2015. 333-334.; Kránitz i. m. (7. 1j.) 23-24., 36-37.

23 Kocsis Imre: A hegyi beszéd. Budapest, Jel, 2005. 84.

24 Erdő i. m. (15. lj.) 501-509. 
emberi alkotás - elveszítette önmagában vett szentségi jellegét. ${ }^{25}$ A római és a zsidó felfogás is kiemelt jelentőséget tulajdonított a jognak. A jog mint normarendszer per se (tartalmától elvonatkoztatott) tisztelete az európai jogfelfogást meghatározó római jog sajátja. A római jogtisztelet természetjogi eredetű, és annak része az a „szigorúan jogi axióma", miszerint az emberek természetüknél fogva egyenlők. ${ }^{26} \mathrm{~A}$ jog kiemelt tisztelete jelentette továbbá azt a lépést, amely meghatározta az európai civilizációt. ${ }^{27}$ A mindennapi életet a jog szabályozta, ez a jog pedig - sacrataként - önmagában feltétlen tiszteletet kapott. ${ }^{28}$ Mindez - mint természetjogi tétel, „Róma öröksége” - biztosítékul szolgált arra is, hogy az egyén méltósága semmiképpen ne legyen alávetve az államnak. ${ }^{29}$

A római jogtól eredetében függetlenül, de a jogtiszteletet a keresztény jogfelfogás másik forrásaként mégis különleges szintre emelve - kiemelt szerepe volt az ószövetségi törvénynek. Ebben a jogrendben szintén benne rejlett az ember (istenképiségéből származónak tekintett) méltóságának tisztelete, a szabadság és az igazságosság követelménye és a társadalmi felelősség (mint a szociális jogok előképe). Az ószövetségi zsidó hagyományból nemcsak az egyetlen személyes, teremtő és gondviselő Isten hite és tisztelete származik, amely nélkül a kereszténység nem volna érthető, ${ }^{30}$ hanem a törvény önmagáért (és nem a kikényszerítés miatti) tisztelete is. ${ }^{31}$ Ezt vette át először erkölcsi-teológiai, majd jogi formában is a kereszténység.. ${ }^{32} \mathrm{Az}$ államvallássá válást követően ez az állami cselekvést korlátozó-meghatározó jogfelfogás vált általánossá. ${ }^{33}$ Azt látjuk tehát, hogy a két - történeti és univerzális - jogi értékréteg, illetve az ezeket hordozó jog önmagában vett tisztelete elszakíthatatlan a keresztény (majd tágabban, az európai jogi) hagyománytól. ${ }^{34}$ Annak mindkét gyökerében (a római jogiban és az ószövetségiben) egyaránt felismerhető jogtisztelet töretlenül került át a természetjogi felfogásba ${ }^{35}$ (majd az azt felváltó jogállam-paradigmába).

Összességében tehát a keresztény Egyház joga, a kánonjog a szent tudományok (teológia) közé tartozik, ${ }^{36}$ de már nem az üdvösség forrása (legfeljebb az ahhoz vezető helyes magatartás eszköze). Ezt emeli ki a hatályos egyházi törvénykönyv utolsó, 1752. kánonja, amely szerint „a lelkek üdvösségének az Egyházban mindig a legfőbb

25 Kuminetz Géza: Egy tomista jog- és állambölcselet vázlata, I. Budapest, Szent István Társulat, 2013. 756., 759-764., 767-768.

26 Henry Sumner Maine: Az ösi jog. Budapest, Gondolat, 1988. 18., 20-21., 73.

27 Uo. 77.

28 Zlinszky János: Ius publicum. Budapest, Osiris-Századvég, 1994. 32., 177-179.

29 Uo. 196-197.

30 Kránitz Mihály: Hidak a vallások felé. Budapest, Szent István Társulat, 2014. 22-26.; XVI. Benedek pápa: Verbum Domini, [41]. In XVI. Benedek megnyilatkozásai, I. Budapest, Szent István Társulat, 2018. 239.

31 Szathmári i. m. (18. lj.) 392-393.; Rózsa i. m. (17. lj.) 156-168.

32 Beran Ferenc - Lenhardt Vilmos: Az ember útja. Budapest, Szent István Társulat, 2012. 29-42.

33 Uo. 44-46.

34 Frivaldszky János: Természetjog - eszmetörténet. Budapest, Szent István Társulat, 2001. 50-60.

35 Kecskés Pál: A keresztény társadalomelmélet alapjai. Budapest, Szent István Társulat, 1938. 110-121. 
törvénynek kell lennie”. ${ }^{37}$ Ez a jog pedig a házasság és a család intézményének isteni eredetére és a fennálló szociális háttérre támaszkodva komoly, sőt egyre erősödő támaszt és védelmet jelentett. Ezt mutatják az Egyház saját fegyelmi szabályai, ${ }^{38}$ és ez tükröződik a szabaddá, majd államvallássá emelkedést követő világi (császári) szabályokban is. A házasságot, családot és az ezekhez tartozó személyeket védelmező új szabályok egyrészt a család fennmaradását (támogatások, a rabszolga-életközösségek családként elismerése) szolgálták, másrészt a válás korlátozását, a házasságtörés és az újraházasodás tiltását, az apai és a rabszolgatartó hatalom korlátozását, végül - immár kifejezetten keresztény intézményvédelemként - a vegyes házasságok korlátozását hozták. ${ }^{39}$ Az így megerősödött, hármas - szociális, jogi és szentségi - alapra támaszkodó és ezek védelmét élvező keresztény házasság- és családfelfogás lényegében változatlan maradt a következő közel kétezer év során. ${ }^{40}$

\subsection{Katolikus tanítás ma a házasságról és a családról}

Igazi kihívás a katolikus házasságot és családot csak a felvilágosodás hatására, különösen a 19. század második felétől, a polgári házasságjog és annak részeként a polgári házasság felbontásának lehetősége folytán érte, ${ }^{41}$ ezek hatása pedig az utóbbi évtizedekben vált kritikussá, amikor a tartósan monogám házasság már csak az egyik lehetséges együttélési forma. A felbonthatatlanság jegye még a katolikus házasságokat sem képes egyben tartani, és legújabban már a házasság egy férfi és egy nő életközösségeként történő meghatározása sem kizárólagos. ${ }^{42}$ A folyamatos és egyre erősödő kihívás következtében a Katolikus Egyház - bár sem szentségi, ${ }^{43}$ sem szociális megközelítésben nem változott a felfogása és tanítása ${ }^{44}$ - egyre jobban hangsúlyozni kényszerült a család szerepének fontosságát.

37 Erdő i. m. (15. 1j.) 809.; részletes értelmezéséről: Erdő Péter: Az élő Egyház joga. Budapest, Szent István Társulat, 2006. 73-75.

38 Ld. a 8. lábjegyzetben felsorolt műveket.

39 Sáry Pál: Pogány birodalomból keresztény birodalom. Budapest, Szent István Társulat, 2009, 30-39., 49-50.

40 Arno Anzenbacher: Keresztény társadalometika. Budapest, Szent István Társulat, 2001. 81-86.

41 Szladits Károly: A magyar magánjog vázlata, II. Reprint kiadás, Pécs, Ponte Press, 1999. 310-314.; Eörsi Gyula: Összehasonlító polgári jog. Budapest, Akadémiai, 1975. 345.; Lábady Tamás: A magánjog általános tana. Budapest, Szent István Társulat, 2013. 30-32.; Jobbágyi Gábor: Magyar polgári jog, I. Budapest, Szent István Társulat, 2013. 153-155., 161-164.

42 Jobbágyi i. m. (41. lj.) 161.

43 A Katolikus Egyház Katekizmusa (KEK), 1601-1666. A házasság szentségi jellegének tárgyalására a dolgozat nem vállalkozik, ezért a semmisségi perek általános bemutatására, ezek legutóbbi változására (ld. Hársfai Katalin: A házassági semmisségi perek a DC után. Budapest, Szent István Társulat, 2013; vagy Ferenc pápa: Mitis Iudex Dominus Iesus. Az Úr Jézus, aki szelíd bíró. Budapest, Szent István Társulat, 2015), illetve az elváltak és újraházasodottak Eucharistiához járulásának kérdéseire (Ferenc pápa: Amoris laetitia. A családban megélt szeretetről kezdetü apostoli buzditása. Budapest, Szent István Társulat, 2016 nem tér ki.

44 Összevetve: Kecskés i. m. (35. lj.) 188-201. és Az Igazságosság és Béke Pápai Tanácsa: Az Egyház társadalmi tanitásának kompendiuma. (ETTK) Budapest, Szent István Társulat, (2004) 2007, 123-143.; KEK 2196-2233., 2357-2400., 2514-2533. 


\subsubsection{A II. Vatikáni Zsinat a házasságról és a családról}

A II. Vatikáni Zsinat hosszú vita után, az utolsó ülésszak bezárás előtti utolsó munkanapján elfogadott ${ }^{45}$ lelkipásztori konstitúciója, a Gaudium et spes második részében önálló fejezetben látta szükségesnek felhívni a figyelmet a házasság és a család méltóságának megbecsülésére. ${ }^{46} \mathrm{~A}$ fejezet a házasság és a család mai világban látható helyzetének, valamint szerepének és rendeltetésének bemutatásával indít. Számba veszi a legnagyobb kihívásokat, a válás járványát, a házasság nélküli rövid idejű együttéléseket és a népesség növekedésére vonatkozó félreértéseket. ${ }^{47}$ Rögtön ezt követően megerősíti az Egyház meggyőződését a házasság szent (Istentől rendelt) és szentségi (Jézus Krisztus által alapított, az üdvösséghez vezető jel) voltáról. Igen lényeges, hogy összekapcsolja a házasságot és a családot, és az apai, valamint az anyai méltóságból fakadó nevelést és példamutatást a gyermekek általános és vallási nevelésének eszközeként is bemutatja. ${ }^{48}$ Ezt követően hosszan elemzi a hitvesi szerelem jelentőségét, a házasság termékenységét, továbbá a hitvesi szerelem és az emberi élet tiszteletének összefüggését. ${ }^{49}$ Végül visszatér a házasság és a család gondozásának szükségességére (okaira) és az ezzel kapcsolatos lelkipásztori feladatokra. ${ }^{50}$

A konstitúcióból világosan kiolvasható, hogy a Zsinat a házasságnak és a családnak biológiai szükségszerüsége (a gyermekek nemzésére és felnevelésére irányultsága), valamint szentsége (Isten rendeléséből és konkrét esetben Isten szerzéséből létrejötte) miatt egyaránt nagy jelentőséget tulajdonít: „A házasság intézménye és a házastársi szerelem természetszerủleg a gyermek nemzésére és nevelésére irányul, és ezekben teljesednek be." Illetve:

„az emberek Üdvözítője és az Egyház Vőlegénye a házasság szentsége által elébe jön a keresztény hitvestársaknak. Velük is marad, hogy miként ő szerette az Egyházat, és önmagát adta érte, ugyanúgy szeressék egymást a házastársak is, kölcsönös odaadással és örök hűséggel. Az igazi házastársi szerelem fölvétetik az isteni szeretetbe, s Krisztus megváltó ereje és az Egyház üdvözítő tevékenysége irányítja és gazdagítja."51

Ha ehhez hozzávesszük a fejezet utolsó részében olvasható feladatszabást, amely a házasság ápolásában, a gyermekek nevelésében mindazokra kötelességet ró, akik

45 John W. O’Malley: Mi történt a II. Vatikáni Zsinaton. Budapest, Jezsuita, 2015. 353-359., 362-367., 382., 387-392.; Goják János: Bevezetés. In A II. Vatikáni Zsinat dokumentumai. Budapest, Szent István Társulat, 2007. 607-648.

46 II. Vatikáni Zsinat: Gaudium et spes (1965). S47-52. In Diós István (szerk.): A II. Vatikáni Zsinat dokumentumai. Budapest, Szent István Társulat, 2007. 691-699.

47 Uo. 47.

48 Uo. 48.

49 Uo. 49-51. A kérdés körül a zsinaton különösen nagy vita volt, amit Szent VI. Pál pápa a zsinat után négy évvel kiadott Humanae vitae kezdetű enciklikájával zárt le, l. O’Malley i. m. (45. lj.) 389-390.

50 Gaudium et spes, S52.

51 Uo. 48. 
kapcsolatban vannak vele, így a szülőkre, a polgári hatalomra, a többi keresztény hívőre, a lelkipásztorokra, különösen a papokra, a hittudósokra, a világi tudományok művelőire és minden más szervezetre, akkor nem lehet kétségünk, hogy az Egyház figyelme kiemelten fordult a házasságban élő, illetve annak gyümölcseként családban élő apa-anya-gyermekek szeretetközösség felé. A házasság és a család immár nem természetes adottság, nem társadalmilag elvárt és az Egyház által helyeselt együttélési forma, hanem hivatás, missziós szeretetközösség:

„az élő Isten képmásává alkotott és a személyiség méltóságával fölruházott házastársak forrjanak össze a szeretetben, azonos gondolkodásban és egymás kölcsönös megszentelésében kövessék Krisztust, az élet forrását; hivatásuknak örömeiben és áldozataiban és hűséges szerelmükkel is tanúskodjanak annak a szeretetnek misztériumáról, amelyet az Úr nyilatkoztatott ki a világnak halálával és föltámadásával."52

\subsubsection{A Gaudium et spes hatása}

A Zsinat tanítása valóban gyümölcsözőnek bizonyult. VI. Pál pápa 1968-ban kiadott Humanae vitae enciklikája ugyan közvetlenül az élet továbbadására, így a házasság kötelékétől elszabaduló szexualitás és a fogamzásgátlás értékelésére irányult, a kérdést azonban a szülői felelősség és a házasság összefüggésére támaszkodva értékelte. ${ }^{53}$ Ehhez - az ember egységben szemlélése érdekében - kimondva a Gaudium et spes konstitúcióra támaszkodott, ${ }^{54}$ megismételve és kifejtve a házasság lényegi vonásait, ennek részeként az élet továbbadását, valamint a szülői szerepet, amelynek a teremtő Isten terveihez kell igazodnia. ${ }^{55}$

Szélesebb szempontokra vonatkozóan ad iránymutatást a család feladatairól Szent II. János Pál pápa 1981-ben, 13 hónappal „A keresztény család feladatai a mai világban" témát vizsgáló VI. Püspöki Szinódus után kiadott, a szinódus eredményeit öszszefoglaló Familiaris consortio apostoli buzdítása. ${ }^{56} \mathrm{~A}$ szent pápa már világosan érzékelte, hogy a család hagyományos szerepe visszaszorulóban van:

„Abban a történeti helyzetben tehát, amelyben a család ma él, a fény és a sötétség egyaránt jelen van [...] a válások száma egyre növekszik, s a hívők új életközösségre lépnek: csupán polgári házasságra, amely ellenkezik a megkeresztelt emberek hivatásával, a felszólítással, hogy »az Úrban kössenek házasságot«; illetve a nem hitből, hanem más indítékok miatt kötött szentségi házasságra; továbbá

52 Gaudium et spes, S52. 52.

53 VI. Pál pápa: Humanae vitae (1968). 1-2.

54 Uo. 7.

55 Uo. 9-10.

56 II. János Pál pápa: Familiaris consortio (1981). Előszó. 
[a Szinódus atyái] rávilágítottak azoknak az erkölcsi normáknak elvetésére, melyek a nemiség emberi és keresztény gyakorlatát szabályozzák a házasságban".57

A buzdítás ezért a zsinati konstitúciónál is egyértelműbben és részletesebben fogalmazza meg a házasság és a család teológiai jelentőségét (Isten terve a családról és a házasságról; A házasság az Isten és az ember közötti szövetség képe; Jézus Krisztus és a házasság szentsége; A gyermekek a házasság legdrágább ajándékai), ${ }^{58}$ amelynek következtetése az, hogy „az Egyház a szentségben született családban találja meg a maga bölcsőjét, valamint azt a helyet, ahol az emberi nemzedékekkel való találkozást megélheti, s viszont: az emberi nemzedékek itt találkozhatnak az Egyházzal".59 A házasság missziós feladata itt már félreérthetetlen: Isten közelségében kell maradnia, és a következő nemzedékeket Istenhez kell vezetnie. A missziót megvalósító személyes - apára, anyára, a házastársakra együtt, a gyermekekre háruló - feladatok részletes bemutatása után hosszan értékeli a család nevelő szerepét.

„A keresztény szülők nevelői feladata - amely mint fentebb mondtuk, abban gyökerezik, hogy a szülők a teremtő Isten munkatársai - új és sajátos forrást nyer a házasság szentségében, amely gyermekek keresztény nevelésére szenteli őket. Arra kapnak tudniillik meghívást, hogy részük legyen az Isten atyai és Krisztus pásztori szeretetében és tekintélyében, valamint az Egyház anyai szeretetében. A szentség felruházza őket a bölcsességgel, a jó tanáccsal, az erősséggel és a Szentlélek összes többi ajándékával, amelyekkel segíthetik gyermekeik emberi és keresztény érlelődését." 60

A megfogalmazás újszerűsége egészen világos: míg a korábbi évszázadokban a család a társadalom és az Egyház természetes szociális valósága volt, amely mintegy magától látta el nemcsak az élet továbbadásának, hanem a nevelési feladatokat is, a 20. század végére ez már nem magától értetődő. Immár a házasság és a család önként, a korszellem ellenére vállalt, kihívásokkal szembenéző elkötelezettség, amelynek része - és ezt szintén önként kell vállalni és teljesíteni - a nevelés, mégpedig a kereszténnyé nevelés missziója mint „sajátosan és eredeti módon egyházi feladat”, 61 evangelizációs egyházi szolgálat. ${ }^{62}$

A Familiaris consortio nagyon konkrét helyzetelemzését és gyakorlati útmutatásait tükrözi vissza az 1983-ban jóváhagyott egyházi törvénykönyv, ${ }^{63}$ valamint az 1997-ben kiadott Katekizmus is. ${ }^{64}$ Újabb negyedszázad elteltével, 2004-ben egy

57 II. János Pál pápa: Familiaris consortio i. m. (56. lj.) 6-7.

58 Uo. Második rész címe és 11-13.

59 Uo. 15.

60 Uo. 38.

61 Uo. 50.

62 Uo. 52-53.

63 Az egyházi törvénykönyv, 1055-1065. kánon.

64 KEK 2196-2233., 2357-2400., 2514-2533. 
még részletesebb, ugyanakkor általánosabb dokumentum készült el Szent II. János Pál pápa megbízásából, $A z$ Egyház társadalmi tanitásának kompendiuma, amely önálló fejezetben vizsgálja a család társadalmi és egyházi szerepét. ${ }^{65} \mathrm{~A}$ dokumentum általánosabb, mert nem kizárólag a család kérdésköre a témája, és nem csak a katolikusoknak szól. ${ }^{66}$ Ugyanakkor konkrétabb, mert gyakorlati szempontokat is tárgyal (például a nevelés tekintetében vagy a család és a társadalom együttmunkálkodását illetően). Hatása - újabb közel egy évtized múlva - felismerhető: az Egyháznak a család értékeit kell kiemelnie, és ezekre tekintettel kell a családokat támogatnia. ${ }^{67}$

Ez utóbbi törekvés a későbbiekben nehezen volt tartható. Mi sem mutatja ezt jobban, mint az a körülmény, hogy egymást követö években két szinódus is megvitatta a család hivatását és küldetését. A III. rendkívüli Püspöki Szinódus 2014-ben A család lelkipásztori kihívásai az evangelizáció kontextusában címmel kiadott relatiójában már kifejezetten konfrontatív helyzetet volt kénytelen elemezni a család katolikus felfogása és a társadalmi valóság között. Nem véletlen ezért, hogy a dokumentum egyik utolsó következtetése szerint a családot alapvető kihívások veszélyeztetik, amelyeknek nehezen tudnak ellenállni, holott a családokra hárul az evangelizálás feladata, ezért az Egyháznak ebben támogatnia kell őket. ${ }^{68}$

Az egy évvel később tartott XIV. rendes Püspöki Szinódus ugyanezt a kérdéskört vizsgálta tovább $A$ család hivatása és küldetése az Egyházban és a mai világban címmel ellátott záróokmánya szerint. ${ }^{69} \mathrm{~A}$ családot érő szociokulturális, antropológiai kihívások és feszültségek bemutatása után, amelyek következtében a 21. század minden családja veszélyeztetett és törékeny, a dokumentum röviden elemzi az Egyház tanítását, különösen a II. Vatikáni Zsinat után eltelt időszakra, részletesen kitérve az egyes pápák szerepére. Végül gyakorlati szempontok megjelölésével kísérel meg segítséget nyújtani a lelkipásztoroknak és a családoknak a közös egyházi evangelizációs feladat ellátásában, kitérve természetesen a nevelés általános és keresztény szempontjaira. Nem lehet egyértelmủbben megfogalmazni ezt a szerepet, mint ahogyan az az okmány zárószakaszában szerepel: „A megkereszteltek családja természeténél fogva misszionárius, és saját hite növekszik, amikor átadja azt másoknak, elsősorban saját gyermekeinek. [...] A család ily módon a pasztorális tevékenység alanya." ${ }^{\prime 70}$

A záródokumentum figyelembevételével adta ki Ferenc pápa az Amoris laetitia apostoli buzdítást. ${ }^{71} \mathrm{Az}$ exhortatio nem mellőzi a családot ért kihívásokat, ugyanakkor a házasság és a család isteni eredetére, szépségére és küldetésére helyez nagyobb

65 ETTK 123-143.

66 ETTK 17-19.; Angelo Sodano bíboros államtitkár 2004. június 29-én kelt, Renato Raffaele Martino bíboroshoz, az Igazságosság és Béke Pápai Tanácsa elnökéhez címzett levele.

67 Várnai Péter: Jegyeseknek a családról a zsinat után. In Pákozdi István (szerk.): Öt évvel a lelkipásztori zsinat után. Budapest, Vigília, 2013. 130-143.

68 III. Extraordinary General Assembly of the Synod of Bishops: The Pastoral Challenges of the Family in the Context of Evangelization. Vatikán, 2014. 60-61.

69 A család hivatása és küldetése az Egyházban és a mai világban. A püspöki szinódus 14. rendes közgyủlésének (2015. október 4-5.) záróokmánya. Budapest, Szent István Társulat, 2015.

70 Uo. 92-93.

71 Ferenc pápa (2016) i. m. (43. lj.). 
hangsúlyt. A hatodik fejezetben az utóbbi két szinódus következtetéseinek ad apostoli tekintélyt: a család az evangelizáció alanya, a nevelés legfontosabb helye. A család a katekézis, a hitre nevelés nélkülözhetetlen eszköze és szereplője. ${ }^{72}$

\subsection{A Magyar Katolikus Egyház a házasságról és a családról}

A házasság és a család szerepét érő kihívásokkal és támogatási igénnyel nemcsak a világegyház, hanem Magyarország Katolikus Egyháza is szembesült, ezért megkísérelt válaszokat keresni. A rendszerváltozást követően, amint a nyilvános megszólalások lehetősége megnyílt, a II. Vatikáni Zsinat és Szent II. János Pál pápa megnyilatkozásainak ismeretében megjelentek a Magyar Katolikus Püspöki Konferencia első szociális tartalmú körlevelei. ${ }^{73}$ Ezek sorába illeszkedik az 1993 karácsonyán kiadott Körlevél a Család Nemzetközi Éve megnyitására, az 1994 karácsonyán kiadott Körlevél a Család Nemzetközi Éve befejezése alkalmából, valamint az öt év múlva, 1999 karácsonyán kiadott $A$ boldogabb családokért körlevél. ${ }^{74}$

Az 1993-as körlevél kifejezetten lelkipásztori hangvételü. Rögzíti, hogy „[a] keresztény család tanúságtétel Istenről, aki maga a szeretet. Tanúságtétel arról, hogy Isten a Szentháromság személyeinek egységében az emberi család ősmintája, [...] tanúságtétel Istenről, aki a szeretet, aki úgy szerette a világot, hogy egyszülött Fiát adta, hogy a Szentlélekben ajándékozza magát nekünk és új életet ültessen - a szívünkbe", ezért az evangelizáció tárgya és alanya, hitvallás és tanúságtétel. Hasonló hangvételü az 1994-es körlevél is, amely viszont már kiemeli, hogy „[a] család alapvető feladata az élet szolgálata, ami azonban szorosan összekapcsolódik a nevelés feladatával", miközben utal a család intézményének társadalmi hatásokra kialakult válságára (a Szent II. János Pál pápa által használt „halál civilizációja” fordulatot is említve).

Az 1999-es nagy (153 szakaszból álló, az összes eddig említett és néhány további zsinati, ${ }^{75}$ apostoli és szentszéki dokumentumot felhasználó) körlevél már egészen más hangnemet használ. Eleve nemcsak a hívekhez, hanem „minden jóakaratú emberhez" szól. Ennek megfelelően első harmadában (1-50. szakasz) nem kifejezetten a keresztény házasság- és családfelfogást elemzi, hanem az európai és a magyarorszá-

72 Ferenc pápa (2016) i. m. (43. lj.) 199-258.

73 Magyar Püspöki Kar: Pásztorlevél a magzati élet védelméről (1992). Elérhető: https://regi.katolikus.hu/konyvtar.php?h=156 (A letöltés dátuma: 2020. 10. 08.); Magyar Püspöki Konferencia: Igazságosabb és testvériesebb világot! (1996). Elérhető: https://regi.katolikus.hu/konyvtar. php?h=184 (A letöltés dátuma: 2020. 10. 08.)

74 Magyar Püspöki Kar: Körlevél a Család Nemzetközi Éve megnyitására (1993). Elérhető: https://regi. katolikus.hu/konyvtar.php?h=302 (A letöltés dátuma: 2020. 10. 08.); Magyar Püspöki Konferencia: Körlevél a Család Nemzetközi Éve befejezése alkalmából (1994). Elérhető: https://katolikus.hu/ dokumentumtar/2874 (A letöltés dátuma: 2020. 10. 08.); Magyar Püspöki Kar: A boldogabb családokért (1999). Elérhető: https://regi.katolikus.hu/konyvtar.php?h=156 (A letöltés dátuma: 2020. 10. 08.)

75 Családjogi Charta. (1983); Hittani Kongregáció: Donum vitae (1987). Elérhető: https://regi.katolikus.hu/konyvtar.php?h=187 (A letöltés dátuma: 2020. 10. 08.); II. János Pál: Evangelium vitae (1995). Elérhető: https://regi.katolikus.hu/konyvtar.php?h=78 (A letöltés dátuma: 2020. 10. 08.) 
gi társadalmi helyzetéről ad részletes értékelést. Ennek összképe kifejezetten negatív: a házasságot és az azon alapuló családot érő kihívások folytán mindkét intézmény válságjegyeket mutat. ${ }^{76}$ Éppen ezért a körlevél második harmada (51-87. szakasz) a házasság és a család társadalmi értékét, annak megkülönböztető, semmilyen más életközösségben meg nem jelenő értékeit mutatja be. Végül a körlevél utolsó harmada (88-153. szakasz) már a katolikus tanítást helyezi a középpontba. Kiindulópontja és alapvető megközelítése az, hogy „[a]z Egyház a házasságot és a családot Isten teremtő és üdvözitö tervének távlataiban is szemléli". Visszatér a korábbi két körlevél (és a világegyház dokumentumainak) megállapításaihoz (a házasság szentség, ezért felbonthatatlan; a család a Szentháromság mintaképe), kiemelve, hogy a család ősi kifejezés szerint családegyház (ecclesia domestica), ${ }^{77}$ a keresztény élet első iskolája, amely az Egyháznak is éltető alapsejtje, ${ }^{78}$ amelynek feladata az evangélium továbbadása. Külön szakaszok (119-133.) szólnak a családpasztorációs feladatokról, figyelmeztetve arra, hogy ez nem kizárólag a papság feladata, hanem maguknak a családoknak is részt kell venniük benne (említést érdemel, hogy a „nevelés” szó 23-szor fordul elő a szövegben). Ezt ismétli meg a körlevél befejező szakasza: „II. János Pál szavai szerint »a család az egyház első és legfontosabb útja «, a társadalom emberiességének az alapja." ${ }^{79}$

Az 1999-es nagy körlevéllel természetesen nem szűnt meg a Magyar Katolikus Püspöki Konferencia érdeklődése, azt a következő években igen jelentős megnyilatkozások követték.$^{80}$ A körlevél következménye a 2001-ben rendezett nemzetközi konferencia (Neveléssel a boldogabb családokért címmel). ${ }^{81}$ A körlevélhez hasonlóan nem kizárólag belső (katolikus), hanem a társadalommal (az állammal és az állami intézményekkel) folytatott párbeszéd jegyében megrendezett konferencia záróközleménye rögzíti, hogy „[a] családi életre nevelés elsődleges színtere maga a család, ezt a feladatot senki-semmi nem tudja maradéktalanul pótolni. [...] Elsősorban maguknak a családoknak kell szerepet vállalniuk a társadalom családbarát szemléletének

76 Kiemelésre érdemes, hogy a körlevél az állami magatartást (főként a jogszabályokat) is kritikával illeti, ennek fényében kap jelentőséget a 2012-ben hatályba lépett Alaptörvény (mint új kartális alkotmány).

77 A boldogabb családokért 99;; vö. KEK, 1657.

78 A boldogabb családokért 99.; vö. Gaudium et spes,S52.

79 A boldogabb családokért 153.

80 Magyar Katolikus Püspöki Konferencia: Az élet kultúrájáért (2003). Elérhető: https://regi.katolikus. hu/konyvtar.php?h=160 (A letöltés dátuma: 2020. 10. 08.); Magyar Katolikus Püspöki Konferencia: Nyilatkozata a bevezetés előtt álló abortusztablettáról (2005). Elérhető: https://regi.katolikus.hu/ konyvtar.php?h=166 (A letöltés dátuma: 2020. 10. 08.); Magyar Katolikus Püspöki Konferencia: Nyilatkozata a művi meddővé tételről (2006). Elérhető: https://regi.katolikus.hu/konyvtar. php?h=169 (A letöltés dátuma: 2020. 10. 08.); Magyar Katolikus Püspöki Konferencia: Állásfoglalás a bejegyzett élettársi kapcsolatról (2007). Elérhető: https://katolikus.hu/dokumentumtar/2700 (A letöltés dátuma: 2020. 10. 08.); Magyar Katolikus Püspöki Konferencia: Közleménye a bejegyzett élettársi kapcsolatról szóló törvényről (2009). Elérhető: https://regi.katolikus.hu/konyvtar. php?h=228 (A letöltés dátuma: 2020. 10. 08.)

81 Radnai József (szerk.): Neveléssel a boldogabb családokért. Budapest, Országos Lelkipásztori Intézet - Corvinus, 2001. 
kialakításában. [...] A személyiség formálásának leghatékonyabb eszköze a közvetlen élettapasztalat." 82

\section{Következtetések}

Összefoglalva a fentiekben vázlatosan bemutatott történeti, társadalmi, vallási és jogi megközelítéseket, azt tapasztaljuk, hogy az európai kultúra a gyökereitől fogva a férfi és a nő tartós (habár nem feltétlenül mindig felbonthatatlan) életközösségére építette társadalmi berendezkedését. Mindez természetesen nem zárja ki a más (akár azonos nemủ személyek közötti) kapcsolatok jelenlétét, akár tudomásul vételét sem, még kevésbé jelenti azt, hogy a családi kapcsolatok alapja a házasság minden esetében zavartalan lett volna. Azt viszont igen, hogy minden más szabály, társadalmi viselkedési norma, szokás kimondva vagy természetes tényként erre épült. ${ }^{83}$ Nyilvánvalóan a társadalomfelfogást legalább másfél évezreden keresztül meghatározta a kereszténység. Ezt szintén bemutattam (még ha ennek alapvető összetevőjét, a szakramentális alapokat szándékosan ki is hagytam).

Elmondható tehát, hogy az ószövetségi zsidó összefonódó (mi több szétválaszthatatlan) vallási és társadalomfelfogást átvevő és az azzal legalább ebben a vonatkozásban összhangban álló római társadalom- és jogfelfogáshoz illeszkedő kereszténység gondolkodása a házasságról és a családról meghatározta, mégpedig alapjaiban azt, amit európai kultúrának nevezünk. Ezt a szoros kötődést igazolja vissza az utóbbi nagyjából fél évszázad nemzetközi jogi felfogása is, kezdve az EJENY-nyel, amely csak a legutóbbi évtizedekben kísérelt meg eltávolodni a gyökereitől ${ }^{84}$ - nagy valószínűséggel hosszú távon vagy eredménytelenül (mivel lényegi kulturális összetevőről van szó) ${ }^{85}$ vagy pedig egy más kultúrát létrehozva.

\section{Irodalomjegyzék}

II. Vatikáni Zsinat: Gaudium et spes (1965). Elérhető: http://tarsadalomformalas.kife.hu/a-ii-vatikani-zsinat-gaudium-et-spes/ (A letöltés dátuma: 2020. 10. 08.)

III. Extraordinary General Assembly of the Synod of Bishops: The Pastoral Challenges of the Family in the Context of Evangelization. Vatikán. 2014.

A család hivatása és küldetése az Egyházban és a mai világban. A püspöki szinódus 14. rendes közgyűlésének (2015. október 4-25.) záróokmánya. Budapest, Szent István Társulat, 2015.

Anzenbacher, Arno: Keresztény társadalometika. Budapest, Szent István Társulat, 2001.

82 Radnai i. m. (81. lj.) 12-13.

83 Frivaldszky János: Család (katolikus, természetjogi szemmel). In Pásztor Péter (főszerk.): Magyar politikai enciklopédia. Budapest, Mathias Corvinus Collegium - Tihanyi Alapítvány, 2019. 98-100.

84 Molnár Sarolta Judit: A házasság intézményének perspektívái. Doktori értekezés, Budapest, PPKE JÁK, 2018. Elérhető: http://real-phd.mtak.hu/702/1/Moln\%C3\%A1r_Sarolta_Judit_dolgozatv.pdf (A letöltés dátuma: 2020. 10. 08.)

85 Frivaldszky János: A házasság és a család jogfilozófiai szempontból. In Balásházy Imre - Major Gyöngyi - Farkas Péter (szerk.): Boldogabb családokért és ifjúságért. Budapest, L'Harmattan, 2018. 165-216. 
Az Egyház társadalmi tanitásnak kompendiuma. http://www.vatican.va/roman_curia/pontifical_ councils/justpeace/documents/rc_pc_justpeace_doc_20060526_compendio-dott-soc_hu.html (A letöltés dátuma: 2020. 10. 08.)

Az Igazságosság és Béke Pápai Tanácsa: Az Egyház társadalmi tanitásnak kompendiuma. Budapest, Szent István Társulat, (2004) 2007.

Benedek, XVI., pápa: Verbum Domini. In XVI. Benedek megnyilatkozásai, I. Budapest, Szent István Társulat, 2018.

Beran Ferenc - Lenhardt Vilmos: Az ember útja. Budapest, Szent István Társulat, 2012.

Brósz Róbert - Pólay Elemér: Római jog. Budapest, Tankönyvkiadó, 1989.

Chadwick, Henry: A korai egyház. Budapest, Osiris, 2003.

Eörsi Gyula: Összehasonlító polgári jog. Budapest, Akadémiai, 1975.

Erdő Péter: Egyházjog. Budapest, Szent István Társulat, 2003.

Erdő Péter: Az élő Egyház joga. Budapest, Szent István Társulat, 2006.

Erdő Péter: Az ókori egyházfegyelem emlékei. Budapest, Szent István Társulat, 2018.

Ferenc pápa: Mitis Iudex Domunis Iesus. Az Úr Jézus, aki szelíd bíró. Budapest, Szent István Társulat, 2015.

Ferenc pápa: Amoris laetitia. A családban megélt szeretetröl kezdetü apostoli buzdítása. Budapest, Szent István Társulat, 2016.

Frivaldszky János: Természetjog - eszmetörténet. Budapest, Szent István Társulat, 2001.

Frivaldszky János: Természetjog és emberi jogok. Budapest, PPKE JÁK, 2010.

Frivaldszky János: A házasság és a család jogfilozófiai szempontból. In Balásházy Imre - Major Gyöngyi - Farkas Péter (szerk.): Boldogabb családokért és ifjúságért. Budapest, L'Harmattan, 2018.

Frivaldszky János: Család (katolikus, természetjogi szemmel). In Pásztor Péter (főszerk.): Magyar politikai enciklopédia. Budapest, Mathias Corvinus Collegium - Tihanyi Alapítvány, 2019. 98-100.

Goják János: Bevezetés. In A II. Vatikáni Zsinat dokumentumai. Budapest, Szent István Társulat, 2007.

Hársfai Katalin: A házassági semmisségi perek a DC után. Budapest, Szent István Társulat, 2013.

Hittani Kongregáció: Donum vitae (1987). Elérhető: https://regi.katolikus.hu/konyvtar.php?h=187 (A letöltés dátuma: 2020. 10. 08.)

János Pál, II., pápa: Familiaris consortio (1981). Elérhető: https://regi.katolikus.hu/konyvtar. php?h=202 (A letöltés dátuma: 2020. 10. 08.)

János Pál, II., pápa: Evangelium vitae (1995). Elérhető: https://regi.katolikus.hu/konyvtar.php?h=78 (A letöltés dátuma: 2020. 10. 08.)

Jobbágyi Gábor: Magyar polgári jog, I. Budapest, Szent István Társulat, 2013.

Kardos Gábor: Az emberi jogok nemzetközi védelmének általános kérdései. www.ajkhok.elte.hu/ jegyzettar (A letöltés dátuma: 2020. 10. 08.)

Kecskés Pál: A keresztény társadalomelmélet alapjai. Budapest, Szent István Társulat, 1938.

Kocsis Imre: A hegyi beszéd. Budapest, Jel, 2005.

Kocsis Imre: Bevezetés az Újszövetség kortörténetébe és irodalmába, I. Budapest, Szent István Társulat, 2014.

Kránitz Mihály: Hidak a vallások felé. Budapest, Szent István Társulat, 2014.

Kránitz Mihály: Alapvető hittan. Budapest, Szent István Társulat, 2015.

Kránitz Mihány: A keresztény hit kialakulása és védelme. Budapest, Szent István Társulat, 2018.

Kuminetz Géza: Egy tomista jog-és állambölcselet vázlata, I. Budapest, Szent István Társulat, 2013. Lábady Tamás: A magánjog általános tana. Budapest, Szent István Társulat, 2013.

Magyar Püspöki Kar: Pásztorlevél a magzati élet védelméről (1992). Elérhető: https://regi.katolikus. hu/konyvtar.php?h=156 (A letöltés dátuma: 2020. 10. 08.) 
Magyar Püspöki Kar: Körlevél a Család Nemzetközi Éve megnyitására (1993). Elérhető: https://regi. katolikus.hu/konyvtar.php?h=302 (A letöltés dátuma: 2020. 10. 08.)

Magyar Püspöki Kar: A boldogabb családokért. Budapest, MKPK, (1999). Elérhető: https://regi.katolikus.hu/konyvtar.php?h=156 (A letöltés dátuma: 2020. 10. 08.)

Magyar Püspöki Konferencia: Körlevél a Család Nemzetközi Éve befejezése alkalmából (1994). Elérhető: https://katolikus.hu/dokumentumtar/2874 (A letöltés dátuma: 2020. 10. 08.)

Magyar Püspöki Konferencia: Igazságosabb és testvériesebb világot! (1996) Elérhető: https://regi. katolikus.hu/konyvtar.php?h=184 (A letöltés dátuma: 2020. 10. 08.)

Magyar Katolikus Püspöki Konferencia: Az élet kultúrájáért (2003). Elérhető: https://regi.katolikus. hu/konyvtar.php?h=160 (A letöltés dátuma: 2020. 10. 08.)

Magyar Katolikus Püspöki Konferencia: Nyilatkozat a bevezetés előtt álló abortusztablettáról (2005). Elérhető: https://regi.katolikus.hu/konyvtar.php?h=166 (A letöltés dátuma: 2020. 10. 08.)

Magyar Katolikus Püspöki Konferencia: Nyilatkozat a művi meddővé tételről (2006). Elérhető: https://regi.katolikus.hu/konyvtar.php?h=169 (A letöltés dátuma: 2020. 10. 08.)

Magyar Katolikus Püspöki Konferencia: Állásfoglalás a bejegyzett élettársi kapcsolatról (2007). Elérhető: https://katolikus.hu/dokumentumtar/2700 (A letöltés dátuma: 2020. 10. 08.)

Magyar Katolikus Püspöki Konferencia: Közlemény a bejegyzett élettársi kapcsolatról szóló törvényről (2009). Elérhető: https://regi.katolikus.hu/konyvtar.php?h=228 (A letöltés dátuma: 2020. 10. 08.)

Maine, Henry S.: Az ösi jog. Budapest, Gondolat, 1988.

Molnár Sarolta Judit: A házasság intézményének perspektívái. Doktori értekezés, Budapest, PPKE JÁK, 2018. Elérhető: http://real-phd.mtak.hu/702/1/Moln\%C3\%A1r_Sarolta_Judit_dolgozatv. pdf (A letöltés dátuma: 2020. 10. 08.)

O’Malley, John W.: Mi történt a II. Vatikáni Zsinaton. Budapest, Jezsuita, 2015.

Pál, VI., pápa: Humanae vitae (1968). Elérhető: http://www.vatican.va/content/paul-vi/hu/encyclicals/documents/hf_p-vi_enc_25071968_humanae-vitae.html (A letöltés dátuma: 2020. 10. 08.)

Pap András László: Ki és mi a magyar? Az Alaptörvény preferenciái kritikai perspektívából. In Gárdos-Orosz Fruzsina - Szente Zoltán (szerk.): Alkotmányozás és alkotmányjogi változások Európában és Magyarországon. Budapest, NKE KTK, 2014. 245-264.

Radnai József (szerk.): Neveléssel a boldogabb családokért. Budapest, Országos Lelkipásztori Intézet - Corvinus, 2001.

Rózsa Huba: Bevezetés az Ószövetség könyveibe. Budapest, Szent István Társulat, 2016.

Sáry Pál: Pogány birodalomból keresztény birodalom. Budapest, Szent István Társulat, 2009.

Schanda Balázs: Házasság és család az alkotmányjogban. In Csink Lóránt - Schanda Balázs - Varga Zs. András: A magyar közjog alapintézményei. Budapest, Pázmány Press, 2020. 681-701.

Szathmári Béla: Magyar egyházjog. Budapest, Századvég, 2004.

Szladits Károly: A magyar magánjog vázlata, II. Reprint kiadás, Pécs, Ponte Press, 1999.

Ulpianus, Domitius: Domini nostri sacratissimi principis Iustiniani iuris enucleati ex omni vetere iure collecti digestorum seu pandectarum. Elérhető: www.intratext.com/IXT/LAT0866/_INDEX.HTM (A letöltés dátuma: 2020. 10. 08.)

Varga Zs. András: A házasságra és a családra vonatkozó rendelkezések változása az alkotmányozás során. Iustum Aequum Salutare, 8. (2012), 2. 119-127.

Várnai Péter: Jegyeseknek a családról a zsinat után. In Pákozdi István (szerk.): Öt évvel a lelkipásztori zsinat után. Budapest, Vigília, 2013. 130-143.

Zlinszky János: Ius publicum. Budapest, Osiris-Századvég, 1994. 